\title{
Inner Membrane Amniotic Membrane Tissue
}

National Cancer Institute

\section{Source}

National Cancer Institute. Inner Membrane Amniotic Membrane Tissue. NCI Thesaurus.

Code C133317.

Tissue derived from the inner membrane of amniotic sac. 